\title{
Rhizofiltration for Removal of Inorganic and Organic Pollutants in Groundwater: a Review
}

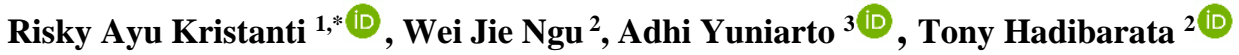 \\ 1 Faculty of Military Engineering, Universitas Pertahanan, Bogor, 16810, Indonesia \\ 2 Department of Environmental Engineering, Faculty of Engineering and Science, Curtin University Malaysia, CDT 250, \\ Miri, Malaysia \\ 3 Department of Environmental Engineering, Faculty of Civil, Environmental and Geo-Engineering, Institut Teknologi \\ Sepuluh Nopember, Surabaya, 60111, Indonesia \\ * Correspondence: risky.kristanti@idu.ac.id;
}

Received: 5.12.2020; Revised: 30.12.2020; Accepted: 2.01.2021; Published: 4.01.2021

\begin{abstract}
Groundwater serves as the water recharge of surface water and provides clean water for domestic, industrial, and agricultural usage for human life. However, rapid developments resulted in groundwater contamination by heavy metals, pesticides, waste by-products, cosmetics, pharmaceutics, and biological agents. Groundwater contamination by the percolation of heavy metals (HM) is focused on in this review. Heavy metals known for their persistence, bioaccumulation, and biomagnification properties are hazardous to live organisms. Long-term exposure to heavy metals brings adverse effects on respiratory diseases, cardiovascular disorders, cancer, etc. They are considered toxins, carcinogens, mutagens, and teratogens for humans in low concentrations. Hence, technologies to remediate heavy metals and organic pollutant in groundwater is vital to prevent environmental and health issues. However, current conventional remediation technologies that are expensive, utilize hazardous materials, and produce toxic by-products in effluents are insufficient to alleviate heavy metals' effects in groundwater. Thus, an eco-friendly and cost-effective rhizofiltration method that adsorb, concentrate, and precipitate contaminants in or on plants' rhizosphere is introduced. This review portrays the mechanisms involved in rhizofiltration to remediate heavy metals-contaminated groundwater and describes the gaps for rhizofiltration to be a commercially viable technology.
\end{abstract}

Keywords: groundwater pollution; heavy metals; biomagnification; bioaccumulation; remediation; rhizofiltration.

(c) 2020 by the authors. This article is an open-access article distributed under the terms and conditions of the Creative Commons Attribution (CC BY) license (https://creativecommons.org/licenses/by/4.0/).

\section{Introduction}

Freshwater is an important water source for the consumption of living organisms on Earth. The freshwater source on Earth is precious and limited. However, due to the rapid growth of the human population and industrialization, limited fresh surface water has been overexploited and polluted, causing insufficient clean water sources available and disruption to the ecosystem. Currently, groundwater is being harvested as a clean water source to fulfil the clean water demand. Groundwater has gradually become an important fresh surface water source to sustain mankind's life apart from rivers and lakes. Groundwater is groundwater that exists in spaces between sedimentary particles and cracks of solid rocks. Groundwater was estimated to become 20 times more than the total volume of surface water. This is vital to human development because groundwater acts as the greatest reserve of drinking water and 
agricultural water [1,2]. The presence of pollutants in the groundwater reduces the availability of clean groundwater. Consumption of contaminated groundwater, which contains different pollutants, s different effects on living organisms, especially health problems. Some efforts have been made to remediate the contaminants from groundwater to conserve the groundwater and ensure a continuous supply of fresh water. With greater depths as compared to surface waters, groundwater should be less contaminated as contaminants need to percolate through the pores and cracks within soils. However, groundwater pollution comes into view as a major issue in many countries, in particular in countries with high industrialization [1]. Contaminants found in groundwater originated from natural and anthropogenic sources include heavy metals, pesticides, waste by-products, cosmetics, pharmaceutics, and biological agents. Among all, the impacts of non-biodegradable HM laden in groundwater raise concerns [2]. Metals and metalloids with a density of more than $5 \mathrm{~g} / \mathrm{cm}^{3}$ are termed as heavy metals [3]. Percolation of pollutant into the groundwater resources generate challenges such as water insecurity due to water quality deterioration and health issues (respiratory diseases, cancers, and cardiovascular malfunctioning) in living organisms $[4,5]$.

To alleviate pollutant toxicity in groundwater, several measures have been made in the last 20 years include (1) identification of pollutant sources for groundwater pollution, (2) limit pollutant emission at sources, and (3) pollutant mitigation of the polluted groundwater resources [2]. Current conventional technologies implemented soil washing, chemical fixation, filtration, and permeable reactive barriers (PRB) are utilized to reduce pollutant concentration in groundwater. However, issues like non-economical, energy-consuming, membrane fouling, low removal efficiency, and production of secondary toxic effluents require treatment methods that are more sustainable $[6,7]$. A method that utilizes pollutant-tolerant plants and associated microbes to remediate polluted sites naturally is that phytoremediation is environmentalfriendly and more cost-effective than conventional engineered techniques [8]. Rhizofiltration is a technique that utilizes the root system of plants to remove a range of contaminants (organic and inorganic), one of the phytoremediation methods that able to alleviate groundwater contamination. The pollutants were absorbed and precipitated in the roots system of the plants from the polluted water. With the interaction between the plants' root system and contaminants in polluted groundwater, the bioavailability of pollutants in the food chain can be significantly diminished [9]. The plants selected for rhizofiltration should have large pollutants accumulation capacity, easily be grown, low cost in maintaining the plants, and produce fewer wastes while the plants are disposed of after the plant's roots are fully saturated by the pollutants. The efficiency of the rhizofiltration was affected by different factors such as plant species, condition of groundwater (temperature and $\mathrm{pH}$ ), and chemical characteristics of organic contaminants. The affecting factors had a limit on the performance of the plants in carrying out rhizofiltration. By considering the factors, the efficiency of rhizofiltration could be maximized, so the remediation rate of organic pollutants in groundwater could be increased.

\section{Sources of Pollutant in Groundwater}

The underground water might be polluted by anthropogenic and natural activities. Anthropogenic activities due to the development caused the seepage of organic pollutants into the groundwater. Some organic contaminants cannot be decomposed by the natural decomposer due to the toxicity, and these contaminants will disrupt the natural ecosystem, especially the aquatic ecosystem [10]. Some organic contaminants exist naturally, especially 
in petroleum. The migration of organic contaminants from petroleum will result in the contamination of groundwater. Solubilization of heavy metal may be occurred through natural processes such as atmospheric deposition, weathering reactions, gas exchange in oceans, volcanic eruptions, and forest fire or though anthropogenic sources like leachate from landfill and mine tailings, liquid wastes disposal in the deep-well, sewage, and industrial spills [6, 11]. Additionally, heavy metal in groundwater can be traced from point (industries, sewage treatment plant, and ships) and non-point sources (oil spillages, domestic run-off, and agricultural run-off) [12]. $\mathrm{HMs}$, in particular $\mathrm{As}, \mathrm{Cd}, \mathrm{Cr}, \mathrm{Hg}$, and $\mathrm{Pb}$, are well-known toxins, carcinogens, mutagens, and teratogens in low concentrations. The impacts of inhalation, ingestion, or direct contact with these HMs are human physical and mental illnesses, mutations, genetic damage, nervous system damage, as well as cancer [13]. Apart from that, essential elements in biochemical reactions for living organisms like $\mathrm{Fe}, \mathrm{Zn}, \mathrm{Cu}, \mathrm{Mn}, \mathrm{Ni}$, and $\mathrm{Co}$ are lethal to humans with their xenobiotic nature. Various illnesses and disorders such as kidney failure, neurological disorders, and cancer can be resulted from them [6]. In short, to diminish the potential exposure to heavy metals, specific source apportionment of heavy metals in groundwater is important. Detailed sources and health impacts for each type of heavy metal and organic pollutant are shown in Table 1.

Table 1. Source and impacts of some contaminant in groundwater.

\begin{tabular}{|c|c|c|c|}
\hline Contaminant & Sources & Impacts & References \\
\hline Lead $(\mathrm{Pb})$ & $\begin{array}{l}\text { Mining, metal smelting, fossil } \\
\text { fuels combustion, sewage, disposal } \\
\text { of waste, fertilizers, pesticides, } \\
\text { paints, batteries, and metal } \\
\text { products }\end{array}$ & $\begin{array}{l}\text { Neurological disorders, skeletal, } \\
\text { endocrine, immune systems damage, } \\
\text { toxicity in the kidney, neurologic and } \\
\text { vascular systems, hypertension and stroke }\end{array}$ & {$[9,14,15]$} \\
\hline Chromium (Cr) & $\begin{array}{l}\text { Timber treatment, dyes, pesticides, } \\
\text { metallurgy, refractory, leather } \\
\text { tanning, and electroplating } \\
\text { industry }\end{array}$ & $\begin{array}{l}\text { Irritation in the stomach and small } \\
\text { intestine, respiratory, kidney, liver, } \\
\text { reproductive systems damage, cancer } \\
\text { (lung, stomach, intestinal tract) }\end{array}$ & {$[9,16]$} \\
\hline Zinc (Zn) & $\begin{array}{l}\text { Mining, metal smelting, fertilizers, } \\
\text { timber treatment, dyes, paints, } \\
\text { wastewater, and electroplating } \\
\text { industry }\end{array}$ & $\begin{array}{l}\text { Diarrhea, liver failure, bloody urine, } \\
\text { icterus, kidney failure, stomach cramps, } \\
\text { abdominal cramps, epigastric pain, } \\
\text { nausea, pancreatic harm, anemia, and } \\
\text { lower levels of high-density lipoprotein } \\
\text { cholesterol } \\
\text { and vomiting }\end{array}$ & {$[9,17]$} \\
\hline Cadmium $(\mathrm{Cd})$ & $\begin{array}{l}\text { Atmospheric deposition, mining, } \\
\text { metal smelting, wastewater, } \\
\text { fertilizers, pesticides, and } \\
\text { herbicides }\end{array}$ & $\begin{array}{l}\text { Renal cancer, infertility, liver, kidney, } \\
\text { cardiovascular and endocrine diseases }\end{array}$ & {$[15,18,19]$} \\
\hline Arsenic (As) & $\begin{array}{l}\text { Atmospheric deposition, volcanic } \\
\text { activity, mineral dissolution, } \\
\text { mining, metal smelting, fossil fuels } \\
\text { combustion, disposal of waste and } \\
\text { coal fly ash, timber treatment, } \\
\text { pesticides, and herbicides }\end{array}$ & $\begin{array}{l}\text { Cancer (skin, bladder, and lung), } \\
\text { cardiovascular illnesses, peripheral } \\
\text { neuropathy, and diabetes }\end{array}$ & {$[8,20-22]$} \\
\hline Iron $(\mathrm{Fe})$ & $\begin{array}{l}\text { Mining, metal smelting, traffic } \\
\text { pollution, and iron industry }\end{array}$ & $\begin{array}{l}\text { Hepatic fibrosis, cirrhosis, hepatocellular } \\
\text { cancer, cardiac disease, hepatic damage, } \\
\text { and diabetes }\end{array}$ & {$[23,24]$} \\
\hline Mercury $(\mathrm{Hg})$ & $\begin{array}{l}\text { Volcanic activity, forest fire, } \\
\text { mining, fossil fuels combustion, } \\
\text { fertilizers, and fumigants }\end{array}$ & $\begin{array}{l}\text { Neurological diseases, } \\
\text { cardiovascular toxicity, disrupting } \\
\text { endocrine systems, impaired growth and } \\
\text { development, reduced reproductive } \\
\text { success, induced liver and kidney damage, } \\
\text { sensory disturbance, visual field }\end{array}$ & {$[25,26]$} \\
\hline
\end{tabular}




\begin{tabular}{|c|c|c|c|}
\hline Contaminant & Sources & Impacts & References \\
\hline & & $\begin{array}{l}\text { constriction, deafness, ataxia, dysarthria, } \\
\text { and immunomodulation }\end{array}$ & \\
\hline Copper $(\mathrm{Cu})$ & $\begin{array}{l}\text { Mining, metal smelting, fertilizers, } \\
\text { fungicides, timber treatment, } \\
\text { wastewater, and electroplating } \\
\text { industry }\end{array}$ & $\begin{array}{l}\text { Epigastric torment, gastrointestinal } \\
\text { bleeding, diarrhea, spewing, tachycardia, } \\
\text { hematuria, respiratory challenges, } \\
\text { hemolytic anemia, hepatocellular } \\
\text { putrefaction in the liver, intense tubular rot } \\
\text { in the kidney, and demise }\end{array}$ & {$[9,17,27]$} \\
\hline Nickel (Ni) & $\begin{array}{l}\text { Volcanic activity, forest fire, } \\
\text { landfill, mining, gas exchange in } \\
\text { the ocean, disposal of waste, steel, } \\
\text { electroplating and cement } \\
\text { manufacturing, wastewater, alloys, } \\
\text { and batteries }\end{array}$ & $\begin{array}{l}\text { Kidney injury, frank haematuria, nausea, } \\
\text { vomiting, hepatic and renal toxicities, } \\
\text { hypothermia, bronchitis, rhinitis, renal } \\
\text { tubular degeneration, neurological } \\
\text { disorders, cancer, incidences of } \\
\text { reproductive and developmental toxicity }\end{array}$ & {$[9,28-30]$} \\
\hline Aluminum $(\mathrm{Al})$ & $\begin{array}{l}\text { Mining, metal smelting, fossil } \\
\text { fuels combustion, and the } \\
\text { aluminum industry }\end{array}$ & Alzheimer disease and memory loss & {$[31]$} \\
\hline Manganese (Mn) & $\begin{array}{l}\text { Mining, metal smelting, fertilizers, } \\
\text { fungicides, steel, and dry battery } \\
\text { manufacturing }\end{array}$ & $\begin{array}{l}\text { Mental illness, neurotoxicity } \\
\text { with extrapyramidal symptoms }\end{array}$ & {$[19,32]$} \\
\hline Antimony (Sb) & $\begin{array}{l}\text { Mining, metal smelting, fossil } \\
\text { fuels combustion, alloy hardeners, } \\
\text { catalysts, flame retardants, } \\
\text { enamels, lead-acid batteries, and } \\
\text { glass decolorants }\end{array}$ & $\begin{array}{l}\text { Kidney disorders, liver poisoning, } \\
\text { damage to respiratory and cardiovascular } \\
\text { system }\end{array}$ & {$[33]$} \\
\hline $\begin{array}{l}\text { Organochlorine } \\
\text { Pesticides }\end{array}$ & $\begin{array}{l}\text { Fertilizer, pesticide, fungicide, } \\
\text { herbicide }\end{array}$ & $\begin{array}{l}\text { Act as neurotoxins which may increase } \\
\text { the risk of Parkinson's disease, increase } \\
\text { infant mortality, endocrine disruptors, act } \\
\text { as carcinogens, damage liver, and } \\
\text { kidneys, reduce the birth rate of reptiles } \\
\text { and birds by causing eggshells thinning, } \\
\text { undergo bioaccumulation and } \\
\text { biomagnification along the food chain }\end{array}$ & [34-41] \\
\hline $\begin{array}{l}\text { Polycyclic aromatic } \\
\text { hydrocarbons }\end{array}$ & $\begin{array}{l}\text { Petroleum, oil spill, forest fire, coal } \\
\text { gasification, liquefying plants. }\end{array}$ & $\begin{array}{l}\text { Increase the risk of chronic obstructive } \\
\text { pulmonary diseases, biochemical } \\
\text { reaction disruptors in the human body, } \\
\text { cause conotruncal heart defects in } \\
\text { newborns, break down red blood cells, } \\
\text { endocrinal disruptors in zebrafish, act as } \\
\text { cytotoxins to microorganisms }\end{array}$ & [42-46] \\
\hline Phthalic acid esters & $\begin{array}{l}\text { Plasticizers, } \\
\text { dispersants, lubricants, } \\
\text { products, pharmaceuticals, food } \\
\text { products. }\end{array}$ & $\begin{array}{l}\text { Damage sperm DNA, damage testis of } \\
\text { mice, and increase the risk of Leydig cell } \\
\text { hyperplasia and cryptorchidism for mice. }\end{array}$ & {$[47,48]$} \\
\hline $\begin{array}{l}\text { Polychlorinated } \\
\text { biphenyls }\end{array}$ & $\begin{array}{l}\text { Plasticizers, stabilizing agents, } \\
\text { electronic components. }\end{array}$ & $\begin{array}{l}\text { Cause hyperlipidemia, increase the risk } \\
\text { of subclinical coronary atherosclerosis, } \\
\text { act as endocrinal disruptors by doubling } \\
\text { the effect of hormones, cause preterm } \\
\text { birth of an infant, alter embryonic } \\
\text { development of zebrafish }\end{array}$ & [49-53] \\
\hline $\begin{array}{l}\text { Benzene, Toluene, } \\
\text { Ethylbenzene and } \\
\text { Xylene }\end{array}$ & $\begin{array}{l}\text { Petroleum, cosmetics and } \\
\text { pharmaceutical } \\
\text { adhesives, inks, }\end{array}$ & $\begin{array}{l}\text { Benzene damages human blood cell, } \\
\text { toluene acts as probable carcinogens to } \\
\text { human, toluene disrupts the human } \\
\text { reproductive system, ethylbenzene } \\
\text { causes acute eyes and skin irritation, } \\
\text { xylene causes breathing difficulty, } \\
\text { xylene causes eyes, nose, and throat } \\
\text { irritation, all undergo biomagnification } \\
\text { and bioaccumulation along the food } \\
\text { chain }\end{array}$ & [54-56] \\
\hline
\end{tabular}




\subsection{Pesticides and fertilizers application.}

To reduce the loss of crop yield in agriculture, pesticides are used to kill the pests feeding on the crops. Some pesticides used extensively in cultivation in the past contained significant concentrations of metals and organic chemicals. Some heavy metals such as $\mathrm{Cu}$, $\mathrm{Hg}, \mathrm{Mn}, \mathrm{Pb}$, or $\mathrm{Zn}$ were used to fabricate insecticides and fungicides. Organochlorine pesticides (OCPs) are usually used to kill pests as OCPs have low cost and high efficiency. However, OCPs contain persistent organic pollutants (POPs), which can only be degraded to less toxic compounds by some natural decomposers [57]. As a result, the OCPs could exist in the environment for a long period since only specific natural microbes can degrade POPs. POPs that may present in the OCPs are dichlorodiphenyltrichloroethane (DDT), polybrominated diphenyl ethers (PBDEs), and dichlorodiphenyldichloroethylene (DDE) [58]. Since infiltration is the process by which water dissolves into the soil [59], the pesticides can seep into the soil together with rainwater and reach the groundwater through infiltration, although OCPs have low water solubility. OCPs are mostly applied in a paddy field during the rice-growing season, so, the concentration of OCPs in the soil will be very high [59]. The accumulation of OCPs in the soil will promote the leaching of more OCPs to reach the groundwater, causing severe groundwater pollution. Although the application of POPs is banned in the Stockholm Convention [60], the persistence characteristics of POPs allow POPs to remain in the environment for a long period. The low application cost attracts some developing countries to continue the use of OCPs containing POPs [61, 62].

Generally, farming was the first main human influence on the soil. Macronutrients and essential micronutrients, including heavy metals $(\mathrm{Co}, \mathrm{Cu}, \mathrm{Fe}, \mathrm{Mn}, \mathrm{Mo}, \mathrm{Ni}$, and $\mathrm{Zn})$ are important components to grow and complete plants. High concentrations of fertilizers are frequently supplemented to soils in effective agriculture systems to offer adequate $\mathrm{N}, \mathrm{P}$, and $\mathrm{K}$ as well as trace amounts of heavy metals for healthy plant growth. The application of fertilizers could increase crop yield in agriculture. Excess application of fertilizers or manure in increasing crop yield leads to groundwater pollution. The fertilizers and manure contain nitrogen, which will increase the nitrogen amount in the groundwater, causing the increment of nutrient content [63]. Organic fertilizer is able to acidize the soil at a slower rate than $0.5 \mathrm{pH}$ in 5 years. When this organic fertilizer dissolves in the water table and reaches the groundwater, groundwater's acidification will occur. The organic pollutants which exist in the fertilizers are polycyclic aromatic hydrocarbons (PAHs) and phthalic acid esters (PAEs) [43, 43]. These organic pollutants could be brought to the nearest surface water through surface run-offs during rain. The surface water's organic pollutants may leech to groundwater since the groundwater is hydraulically connected with surface water [57].

\subsection{Improper sewage management.}

The utilization of some sewage sludge containing livestock manures and composts to land inadvertently leads to accumulating heavy metals in the soil. Even though livestock manure is categorized as organic fertilizers, some heavy metals like $\mathrm{As}, \mathrm{Cu}$, and $\mathrm{Zn}$ were added to animal food in the poultry industry to accelerate the growth and maintain animals' health. Sewage treatment plants treat the sewage collected from residential areas before discharging it into the environment to reduce the environmental impacts. Improper wastewater management in the sewage treatment plant will cause the leakage of sewage water into the environment. The wastewater will pollute the groundwater since the wastewater contains organic contaminants. 
When the sewage water dissolves into the water table, the sewage water will finally reach the groundwater due to the hydraulic seepage flow. Improper sewage sludge management will cause groundwater pollution because sewage sludge usually has a high concentration of organic pollutants, such as Triclosan and fragrances [64]. The condition worsens when the sewage sludge is used to increase soil fertility, causing more crop yield to be harvested in agriculture [65]. The irrigation of sewage sludge applied crop will cause the seepage flow of organic contaminants present in the sludge to the groundwater. The surface run-off will also result in the migration of organic pollutants into nearby surface water, causing the seepage of organic pollutants into the groundwater.

\subsection{Improper industrial effluent management.}

Industrialization has improved the country's economy by increasing productivity, causing more exportation of products. However, some irresponsible industry owners do not treat the effluent before discharging it into the environment to reduce its operational cost. Industrial effluent, which contains chlorophenols, is discharged into the environment without proper treatment from different industries such as wood industries and pharmaceutical industries [66]. Chlorophenols are organic pollutants that have very high chlorination degree with different toxicity [66]. Chlorophenols could leech to groundwater if the effluent containing chlorophenols is discharged without treatment, polluting the groundwater. Apart from chlorophenols, PAHs, volatile organic compounds (VOCs), and alkylphenols (APs) are also present in industrial wastewater [67]. The used synthetic organic chemicals are discharged into the aquatic environment without proper treatment [68]. The organic pollutants present in the surface water source will cause the leaching of pollutants into the soil water and pollute the groundwater.

\subsection{Landfill leachate leakage.}

Engineered landfills are gradually chosen to dispose of municipal solid wastes by burying the solid wastes under the ground with an engineered structure to prevent environmental pollution. The damage of the underground impermeable layer in the landfill will result in the leakage of landfill leachate from the landfill site to pollute the groundwater. Contamination of groundwater can be detected within a $1 \mathrm{~km}$ radius from the leachate leakage site [69]. The leachate characteristics depend on the types of wastes buried in the landfill, which will result in a different composition of organic and inorganic pollutants. Dissolved organic carbon (DOC) in the leachate results from the decomposition of organic wastes in the landfill. DOC may bind with hydrophobic organic contaminants, causing migration of organic pollutants to the groundwater [70]. The transportation of leachate into groundwater can be divided into two, which are dispersion and diffusion. Both of the transportations involve the movement across the geomembrane and clay layer to reach the groundwater [71]. The organic pollutants present in the leachate are PAHs, polychlorinated biphenyls (PCBs), and emerging contaminants. The existence of organic pollutants in the leachate is due to the landfilling of personal care products and pharmaceuticals [72].

\subsection{Mining and petroleum.}

Mining and milling of metal ores are the main factors for metal contamination in the soil. In the mining process, tailings are straight disposed into the environment, resulting in 
elevated heavy metal concentrations. The reclamation process had limitations due to the expensive cost and not effective in restoring soil fertility. Due to world industrialization, the petroleum demand has been increasing, causing the development of technology in extracting petroleum from the ground. However, machinery failure during petroleum exploitation will cause petroleum leakage to the environment. Although petroleum is a natural fossil fuel resource, petroleum contains organic contaminants such as VOCs and PAHs. The VOCs present in petroleum are benzene, toluene, ethylbenzene, and xylene (BTEX) [73]. The oil spills will pollute the groundwater when they occur near the stream, reducing the freshwater availability [74]. The organic pollutants in the petroleum could migrate from the original spot to other places through the groundwater stream. Apart from anthropogenic activities, the petroleum's organic pollutants could be released naturally into the environment through geochemical and biogenic processes [73]. The organic pollutants in petroleum are mostly anthropogenically discharged into the environment [75], so the natural effect of introducing the organic pollutants from petroleum into the environment is rare.

\section{Environmental Fate and Impact of Pollutant in Groundwater}

The existence of organic contaminants in the environment affects the natural environment negatively. It alters human health, causing minor to a severe problems to human health. For heavy metals are well known for their longevity in the environment. They cannot be degraded physically or chemically [6]. To remediate heavy metals in groundwater efficiently, HM toxicity has to be understood. First, heavy metals disrupt the normal metabolism of living organisms by converting to stable oxidation states with proteins and enzymes in the stomach. With their oxidation-reduction and chemical coordination characteristics, original metals from binding sites are displaced by heavy metals, thus cause cell malfunction and toxicity [76].

On the other hand, transport of heavy metals includes pore-water advection, solute dispersion, and convection in the soil. Hence both land and groundwater will be contaminated [77]. Therefore, water quality from the groundwater resources is no longer safeguarded, and sustainable water supply is threatened by the percolation of heavy metals [5]. The use of groundwater for drinking water, industrial and agricultural purposes had increased HM exposure in human beings by direct ingestion of HM from food and water [78]. This exposure is due to the bioaccumulation, biomagnification, and persistence properties of HM [2]. Nonbiodegradable heavy metals bio-accumulate in food through food chains and bio-magnify while transporting from lower to higher trophic levels. Heavy metals' persistence to remain as harmful metals for a long period of time causes long-term risks in the environment. For instance, methylmercury (a toxic chemical form of $\mathrm{Hg}$ ) with a longer half-life can accumulate in the marine food chain after passing through the cell membranes of aquatic life. After biomagnification and bioaccumulation, higher concentrations of $\mathrm{Hg}$ is detected in fishes at higher trophic levels. Nevertheless, heavy metal concentrations depend on the species, location, and trophic level in an ecosystem [2].

\subsection{Human health problem.}

The absorption of OCPs in the human body will damage the nervous system as organochlorine in the OCPs is toxic to neurons in the human body. DDT, which is one type of OCPs, can increase the risk of Parkinson's disease if the individual is frequently exposed to the 
DDT [34]. The neurotoxic OCPs may have a deleterious effect on neuro tissues, affecting communication development in children [35]. The ingestion of OCPs by children will increase the time required for the children to master communication skills. Infant mortality would be increased when pregnant mothers are exposed to OCPs. Even at low OCPs concentration, the exposed mother will give birth to a smaller weight infant [79]. This might occur due to the mother's increment of homocysteine, as the OCPs could alter the homocysteine metabolism [36]. Regular exposure of women to DDE will increase the risk of ovarian cancer as the DDE could promote tumor growth by creating the microenvironment suitable for tumor growth [37]. This shows that OCPs are carcinogens that will induce cancer in an individual under long-term exposure to OCPs. Due to the endocrine system disruption, OCPs could alter insulin secretion and insulin-dependent glucose absorption by increasing the production of reactive oxygen species and peroxynitrite anions in skeletal muscles and beta cells in the pancreas [38]. The ingestion of OCPs by an individual could lead to kidney failure. This is because the presence of OCPs in the human body will damage the liver and kidney, reducing the functional efficiency of the liver and kidney [39]. Inhalation or ingestion of PAHs could reduce lung function and increase the risk of an individual suffering chronic obstructive pulmonary diseases, causing an increment in the cardiovascular death rate [42]. Only some of the PAHs are carcinogenic to humans who will lead to cancer. The mixtures of PAHs could damage the cells and disrupt the biochemical reaction carried out in the human body [43]. When pregnant mothers are exposed to PAHs in the long term, the infants born might suffer conotruncal heart defects due to PAHs' lipophilic characteristics, which allow PAHs to travel across cell membranes and reach the fetus [44]. This will increase the death risk of a newborn. The PAHs could break down the erythrocytes in the human body if many PAHs are consumed [43]. The breakdown of erythrocytes will cause the inefficient transportation of oxygen in the human body as fewer erythrocytes are available in transporting oxygen from the lungs. As a result, the body tissues will suffer oxygen deficiency, and the individual's metabolism rate will be decreased. Although there is lacking study on PAEs' effect on human health, the PAEs could still impact negatively on human health. The oxidative metabolites of di-(2-ethylhexyl) phthalate, which is a type of PAEs, can disrupt and damage the sperm DNA [47]. Damaged sperm DNA may cause infertility of sperm, which will fail fertilization with the ovum. The DNA damage in sperm may also cause infant defects due to the damaged DNA in sperms. As a result, the infant mortality rate and the paternal infertility rate will be increased.

The ingestion of PCBs will cause the individual to suffer hyperlipidemia as PCBs' existence in the human body could increase the number of triglycerides in the blood [49]. The high lipid content in the blood will increase the risk of cardiovascular diseases and obesity. As a result, individuals may have subclinical coronary atherosclerosis. The flow of blood will be restricted by building lipids at the wall of blood vessels [50]. PCBs will disrupt the human endocrine system. It will have the same effect as certain hormones, such as thyroid hormone to the human body [51]. As a result, PCBs will double the effect of certain hormones, altering the growth and development of an individual. The pregnant mothers that are exposed to the PCBs will cause preterm birth of infant [51]. Preterm birth may cause a smaller infant's weight and increase the infant's mortality risk due to incomplete development of certain systems such as the respiratory system. The absorption of BTEX into the human body could disrupt an individual's nervous system in which the BTEX could destroy the nerve cell in the neurons. Benzene in BTEX is highly toxic and could damage the blood cell, causing aplastic anemia and acute myelogenous leukemia [54]. Toluene, a probable carcinogen for humans, will disrupt 
the human reproductive system [54]. Disruption of the reproductive system by toluene might cause the defection of birth and lower fertility in both males and females, which may reduce the birth rate. Ethylbenzene can cause acute eye in which the fluid in the eyes cannot drain properly due to some blockage and skin irritation [54]. Although xylene is not categorized as a carcinogen to humans, the ingestion and inhalation of xylene may lead to eyes, nose, throat irritation, and respiratory problems such as breathing difficulty [56].

\subsection{Natural ecosystem disruption.}

Humanity will be negatively affected by organic pollutants, flora, and fauna and suffer the negative effect of organic pollutants as a result of anthropogenic activities. The groundwater's organic pollutants could travel hydraulically to the surface water [72], causing the terrestrial organisms and aquatic organisms to suffer the negative impact of pollutants. The bioaccumulation and biomagnification of POPs will increase the pollutants content in the consumers along the food chains [40,41]. As a result, the highest trophic level consumers will usually contain the highest POPs in the body. The presence of OCPs in the environment will cause a negative effect on genetics in the reptiles and birds as OCPs will cause the thinning of eggshells [41], reducing the successful eggs hatching chances and thus reducing the population of reptiles and birds. OCPs will change the mating behavior and cause sterility of fauna, causing a low reproduction rate and low birth rate. The existence of OCPs will degrade the natural habitat of flora and fauna [80], causing loss of biodiversity in the contaminated area as the migratable fauna will migrate to a more favorable habitat. In contrast, the flora and fauna which do not migrate from the contaminated habitat might die due to intolerant to contaminants. PAHs are toxic to microorganisms and aquatic life [40]. High content of PAHs in water will kill aquatic life, causing a reduction in aquatic biodiversity. The presence of PAHs in water will alter fish reproduction, altering the population of fish. PAHs will not only cause endocrinal disruption in humans, but PAHs will also disrupt the endocrine system of zebrafish, altering the hormone secretion [45]. PAHs have high lipid membrane interaction potential, which will change the lipid membrane's structure and function, causing cytotoxic to the microorganisms [46].

PAEs will change the microbial function, which will lead to the disruption of ecological balance by changing the microbial community in the ecosystem [81]. PAEs have the potential to negatively affect the endocrine system of animals, which will result in a low reproductive rate. The PAEs could change mice's semen quality and fertility by damaging the testis and increasing the risk of suffering Leydig cell hyperplasia and cryptorchidism [48]. This will reduce the population of mice and might disrupt the natural food web in the ecosystem. Even though the risk of PAEs is not fully confirmed [48], the removal of PAEs from the environment should be carried out to reduce the environmental impact. PCBs will alter the visual development during embryonic development by reducing the photoreceptors in the eyes of zebrafish [52]. This will reduce the survival chance of zebrafish as zebrafish is hard to see the predators due to the reduction of retinal photoreceptors. As a result, a large population decline of zebrafish will occur. PCBs could induce mutations and cause the embryo to develop abnormally [53]. This will reduce the reproductive rate and further reduce the animals' population, causing the loss of biodiversity.

BTEX is highly toxic to the environment [82]. The high toxicity of BTEX will degrade the natural habitat of flora and fauna, causing the migration of flora and fauna to a new habitat. BTEX content in an organism could be increased due to the bioaccumulation and 
biomagnification process [55]. The toxic effect of BTEX will kill the organisms when a large amount of BTEX accumulated in organisms. A high BTEX level will usually be found in the consumer of the highest trophic level, so death will mostly occur among the tertiary consumers.

This will cause ecosystem imbalance, especially when the keystone species are killed. The prey population will be increased due to the decrement of predators, causing the loss of producers on a large scale. Since the ecosystem's biodiversity will be reduced, certain valuable resources will lose before the resources are discovered and exploited.

\section{Current Remediation Technique for Groundwater Contamination}

Application of conventional types of remediation methods is confined by the dispersion of groundwater contaminants in plumes over large areas and deep underground [11]. According to Scullion [83], current remediation technologies for heavy metals in contaminated groundwater have several outcomes in particular: (1) Degradation of pollutants completely or substantially; (2) Extract pollutants for further treatment or disposal; (3) Stabilize pollutants to forms with less mobility or toxicity; (4) Separate non-contaminated substances from polluted substances and treat them before recycling; and (5) Restrict exposure by containing the polluting substances.

The current remediation methods in remediating heavy metals are divided into chemical, biological/ biochemical/biosorptive, and physical-chemical treatment. The discussion of each class of treatment technologies is portrayed in Table 2. In general, chemical treatment technologies can be used for application to control large volumes of contaminants over large areas underground. However, toxic by-products are produced during the reduction process, which cannot be handled satisfactorily. Besides, chemical washing that utilizes strong extractants may deteriorate soil texture and put the soil environment at risk. Lastly, the disadvantage of extracting HM with chelate flushing is that chelating agents are expensive and carcinogenic [11]. In terms of biological, biochemical, and biosorption treatment technologies, biological processes in the sub-surface, particularly phytoremediation, hyperaccumulation, and phytoextraction are not suitable for deep groundwater remediation and is a very slow process. In addition, enhanced biorestoration outnumbered other conventional remediation methods with a long-lasting effect on an aquifer, no waste generation, and no requirement of chemical input. Moreover, biosorption that is cost-effective, non-toxic, easily available, high in adsorption rate, minimum in sludge production, and high in the probability of metal recovery is practical mitigation for HM remediation. However, further scientific research is still needed for this technology [11].

Permeable reactive barriers (PRB) method in physical-chemical treatment technologies may bypass groundwater flow with issues like reduced permeability and clogging. Hence, this technology's regular performance monitoring is required to prevent the barriers' reactivity from being exhausted. Besides that, absorbed HM may regain mobility with the changing soil environment, particularly redox potential and $\mathrm{pH}$. Furthermore, factors like ionic conductivity, porosity, water content, texture, $\mathrm{pH}$, and groundwater flow rate affect the efficiency of electrokinetic remediation in removing HM from groundwater [11]. Overall, further research is needed to ensure the sustainability of remediation techniques is maintained after applying remediation technologies. 


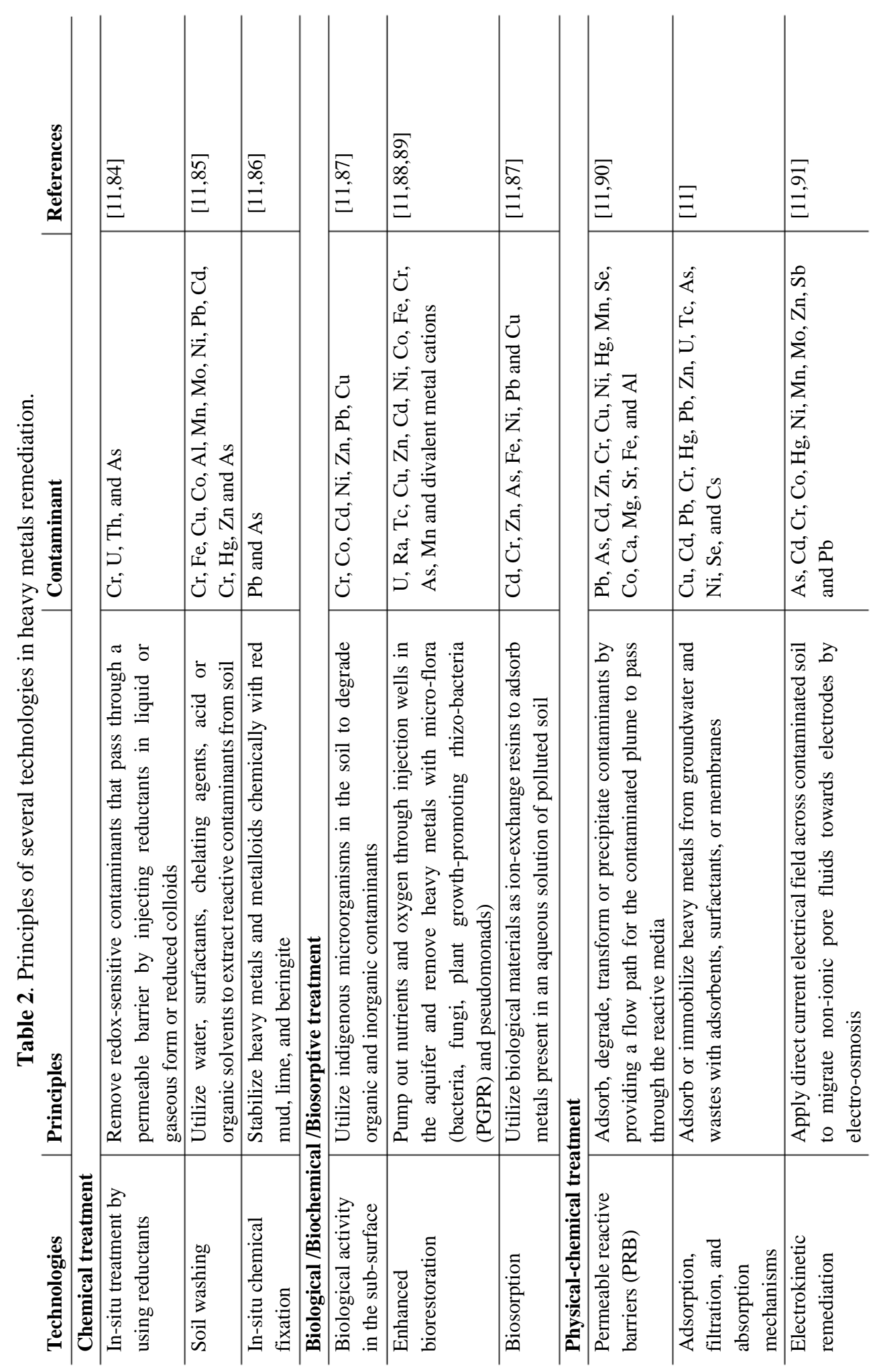

\section{Rhizofiltration in Groundwater Remediation}

Phytoremediation is the use of plant microbe's biological processes to eliminate, attenuate, or transform contaminants from contaminated media like water, soil, and air. This emerging technology is eco-friendly, cost-effective, and energy-saving compared to the current chemical and physical-chemical remediation technologies. In the phytoremediation method, a mechanism known as rhizofiltration is broadly used to remediate polluted groundwater resources [1]. Rhizofiltration uses plant roots in adsorbing contaminants in the surrounding 
root zone (rhizosphere), concentrating and precipitating them on or within the root [12]. Root exudates (secondary metabolites) released by plants' roots will undergo biogeochemical processes that precipitate contaminants on the roots or into the water body. Then, adsorption of contaminants on the roots, within the roots, or translocation to the phyllosphere (plant organs above-ground) will occur according to the type of plant, contaminant species, and concentration [78].

Several heavy metals assist plants' growth and development as they are a vital constituent of various enzymes and proteins. Nonetheless, high concentrations of essential and non-essential HM in plants resulted in heavy metal-associated phytotoxicity that blocks functional groups, displaces essential elements, dismantles membrane integrity, and inactivates enzymes. Thus, the changes in various physiological processes at the molecular or cellular level affect plants' growth and development. The elevated yields of oxygen radicals that interfere with electron transport activities is a common example of heavy metal-associated phytotoxicity [12]. Fortunately, plants developed various defense and tolerance systems that aid them in surviving under phytotoxicity conditions. These include:

a) a symbiotic connection with mycorrhiza which keeps track of movement and uptake of HM ions is established [92] ;

b) utilize plasma membrane to reduce influx [93];

c) store $\mathrm{HM}$ in vacuoles and epidermal tissue with the presence of enzymes such as lipases, proteinases, and phosphatases [12];

d) utilize enzymes (catalases, peroxidases, and superoxide dismutases) and antioxidants (ascorbates, glutathione, $\alpha$-tocopherol, and flavonoids) to neutralize ROS [12]; and

e) produce phytochelatins and metallothioneins that detoxify HM by binding HM to the protein's thiol group [12].

In-situ rhizofiltration can be implemented for contaminated surface water, whereas exsitu rhizofiltration that supplies contaminated water to the plants with an engineered tank system can be used for polluted groundwater resources [78]. Pump and treat (P \& T) system, a physical extraction system that extracts impacted groundwater to above-ground plant hydroponic systems, is applied as ex-situ rhizofiltration. Thus, contaminated plumes underground can be extracted and be filtered through rhizofiltration [94]. According to Singh and Santal [9], the efficiency of hydroponically cultivated roots of terrestrial plants in remediating HM is higher than normal plant-based systems. Rhizofiltration process starts with the identification and extraction of groundwater with the $\mathrm{P} \& \mathrm{~T}$ system. After selected desired plant species with high adsorption of HM from the contaminated plumes, plants are cultivated hydroponically in greenhouses. Plants that acclimatized in the contaminated groundwater and showed high removal efficiency of HMare then planted on the contaminated site.
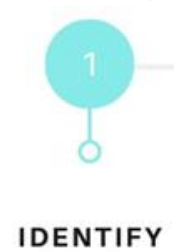

Extract groundwater

that need to be

remediated

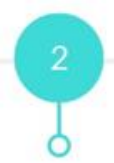

PLANT SELECTION

Plants' roots adsorb

heavy metals and

select plants with high adsorption
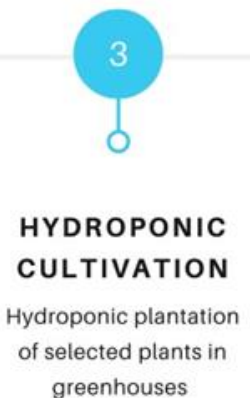

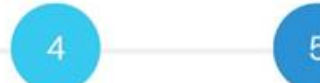

HABITUATION

Plants acclimatized in contaminated groundwater
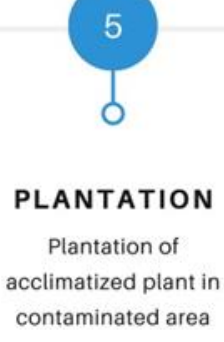

HARVEST

Harvest and dispose plants that are

saturated with heavy metals

Figure 1. Illustration showing the vital steps comprised in the rhizofiltration process of remediating heavy metals in groundwater. 
Consequently, the plants are harvested from the site after their roots are saturated with contaminants. Finally, proper disposal of plants is carried out [12]. A schematic diagram of rhizofiltration processes is illustrated in Figure 1. Other than considering factors that will impact rhizofiltration, plant selection illustrated in Figure 2 is also important to boost HM's removal efficiency [12]. Table 3 showed the plant species that able to remediate heavy metals through rhizofiltration.

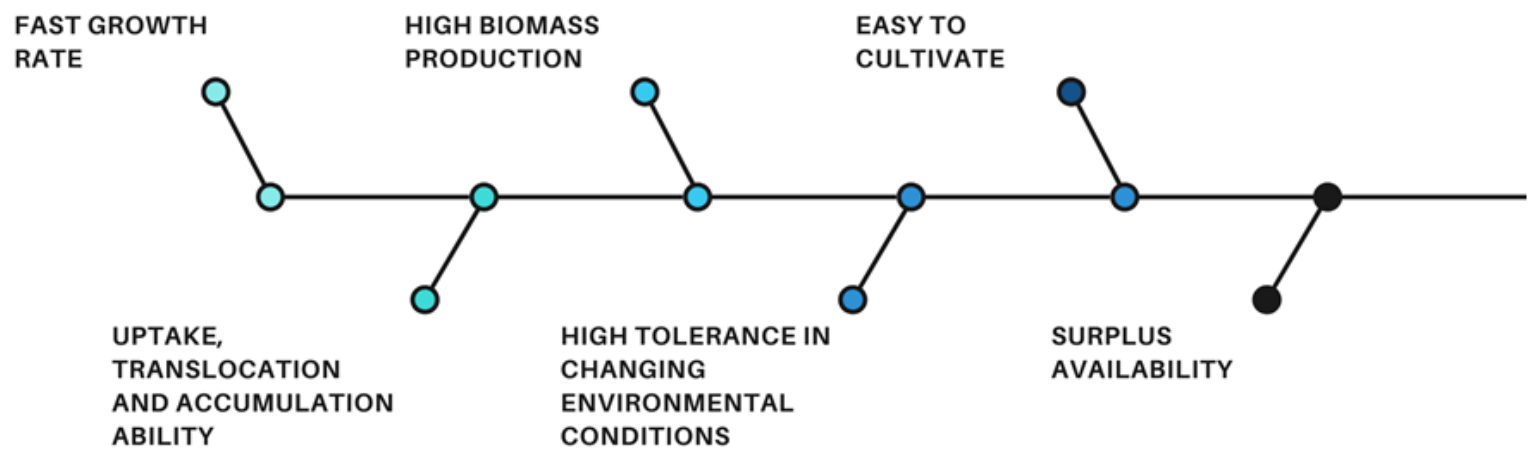

Figure 2. Criteria of plant selection for the rhizofiltration process.

Table 3. Plant species used for the rhizofiltration method in remediating heavy metals and organic contaminant.

\begin{tabular}{l|l|l} 
Heavy metals & Plant species & References \\
\hline Cadmium $(\mathrm{Cd})$ & $\begin{array}{l}\text { Brassica juncea, Setaria italica (L.) Beauv., Pistia stratiotes L., Salvinia } \\
\text { auriculata Aubl., Salvinia minima Baker, domingensis and Azolla filiculoides Lam }\end{array}$ & \\
\hline Lead $(\mathrm{Pb})$ & $\begin{array}{l}\text { Brassica juncea, Oxycaryum cubense (Poep. \& Kunth) Palla, Azolla pinnata, } \\
\text { Carex pendula, Pistia stratiotes L., Salvinia auriculata Aubl., Salvinia minima } \\
\text { Baker, Typha domingensis and Azolla filiculoides Lam }\end{array}$ & \\
\hline Aluminum $(\mathrm{Al})$ & Pistia stratiotes L. and Typha domingensis & {$[97,100]$} \\
\hline Iron $(\mathrm{Fe})$ & Pistia stratiotes L. and Typha domingensis & {$[97,100]$} \\
\hline Manganese $(\mathrm{Mn})$ & $\begin{array}{l}\text { Pistia stratiotes L., Cnidoscolus multilobus, Platanus mexicana, Solanum } \\
\text { diversifolium, Asclepius curassavica } \text { L., and Pluchea sympitifolia }\end{array}$ & {$[97,101]$} \\
\hline Antimony $(\mathrm{Sb})$ & Cynodon dactylon & {$[72]$} \\
\hline Copper $(\mathrm{Cu})$ & Eichhornia crassipes (Mart.) Solms & {$[102]$} \\
\hline Nickel $(\mathrm{Ni})$ & Eichhornia crassipes (Mart.) Solms & {$[102]$} \\
\hline Zinc $(\mathrm{Zn})$ & Eichhornia crassipes (Mart.) Solms and Typha domingensis & {$[100,102]$} \\
\hline Arsenic $(\mathrm{As})$ & Cynara cardunculus & {$[103]$} \\
\hline Synthetic dye & Arundo donax L & {$[104]$}
\end{tabular}

\section{Factors Affecting Rhizofiltration Process}

These factors should be considered to ensure the efficiency of rhizofiltration in remediating the heavy metals and organic contaminants in groundwater, as shown in Figure 3.

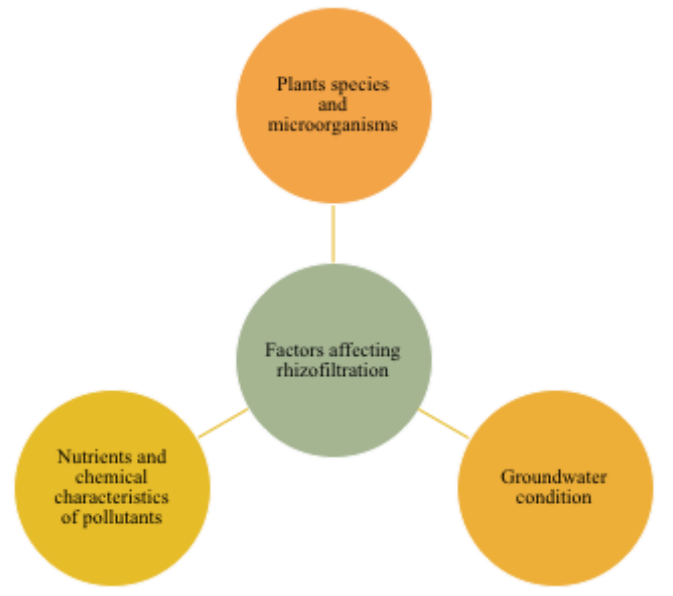

Figure 3. Main factors that affect rhizofiltration. 


\subsection{Characteristics of plant species and microorganisms.}

Different plants will have different efficiency in remediating different organic pollutants as not all plants are suitable for remediating contaminants. For example, intercropping of wheat and maize could accumulate more PAEs from the soil than just a single wheat or maize species could do [105]. The maize and wheat, which are suitable for the rhizofiltration of PAEs may not be applicable in remediating other organic pollutants such as OCPs. Since rhizofiltration is required for groundwater, aquatic plants especially macrophytes could be used in remediating the organic pollutants in the groundwater [106]. The plants with fibrous roots could have greater efficiency in rhizofiltration as fibrous roots have a larger surface area exposed to the contaminants, which will increase the rate of accumulation [87]. Apart from biological factors such as the presence of microorganisms, the presence of other plant species also influences rhizofiltration. With two different species exist in the treatment region, wastewater velocity was slowed, thus, the efficiency of sedimentation and adsorption processes increased [107]. Moreover, the coexistence of various species also yields a better nitrogen removal rate. Additionally, the multispecies system has less sensitivity towards meteorological variations, which boosts the removal efficiency of pollutants [108]. In short, mixed species planted system is favored for wastewater treatment [109]. Microbes in the plants have mutual interaction with plants that will affect the water quality in the rhizosphere. The rhizosphere, the underground region of plants that are constantly exposed to water or sediment, can be interpreted as a highly active zone with microbes' existence. Microbes that require carbon, oxygen and energy from plants boost immunity and aid in mineral exchange in plants. Hence, the rate of nutrient uptake and defense towards phytotoxicity increased with the plantmicrobes interaction [12].

\subsection{Groundwater condition.}

\subsubsection{Time.}

Rhizofiltration process is time-dependent due to biosorption and bioaccumulation mechanisms. A higher number of active sites on biosorbents' surface during the first hour of the biosorption process resulted in a higher adsorption rate of heavy metals. The biosorption process will be prolonged between one and three hours when the amount of active sites reduced and exhausted due to the transfer of adsorbate from outer to inner active sites is undertaken [110]. Begum and HariKrishna [110] reported Hydrilla vercillatta removes $\mathrm{Cu}$ in 10 days with an efficiency of $89.2 \%$ and Fe removal in 5 days with an efficiency of $91.2 \%$. From that, HM's removal rates are determined by optimum contact times, plant species, and type of metals [12].

\subsubsection{Temperature.}

Temperature is a vital factor in increasing the removal efficiency of heavy metals with rhizofiltration. According to Iftikhar [111], heavy metals' biosorption process is significantly dependent on the temperature factor. Increasing temperature enhances the contact between heavy metals and absorber, thus boosting plants' overall absorption performance. Reversely, active absorption sites over the absorber's surface deactivate when temperature decreases, resulting in a diminished absorption rate of heavy metals [111]. In addition, increasing temperature shortens the time needed to reach an equilibrium state in heavy metals' biosorption [111]. 


\subsection{3. $\mathrm{pH}$.}

An environmental condition, such as the $\mathrm{pH}$ of groundwater will affect the efficiency of rhizofiltration [90]. This is because certain $\mathrm{pH}$ might not be suitable for the growth of hyperaccumulators. When the hyperaccumulators are grown in unfavoured $\mathrm{pH}$ condition, the hyperaccumulator will have low uptake of organic contaminants or even die, causing rhizofiltration failure. The concentration of the contaminants in the groundwater may affect the efficiency of the rhizofiltration. Suppose the concentration of the organic pollutants in the groundwater is low. In that case, the hyperaccumulators may not be able to successfully carry out rhizofiltration as the organic pollutants cannot reach the hyperaccumulators' roots [112].

As a result, some of the organic pollutants might travel through the biofilter, which is made of hyperaccumulators. In rhizofiltration, the growing medium's $\mathrm{pH}$ affects biosorption by modifying metals' bioavailability and speciation for plants. During the increase of $\mathrm{pH}$ from strongly acidic to slightly acidic or even neutral value, various hydrolyzed species are detected. A difference in affinity towards active sites is observed. Thus, the high correlation between $\mathrm{pH}$ and affinity towards active sites on plant species is concluded [113]. Besides, $\mathrm{pH}$ dependency can be further clarified in the displacement effect between $\mathrm{H}_{3} 0^{+}$ions and metal ions. Positively charged metal ions will attach to the active sites in the cell wall when the $\mathrm{pH}$ value is increased in the growing medium. However, $\mathrm{H}_{3} \mathrm{O}^{+}$ions gain a high competing effect when $\mathrm{pH}$ is decreased and bind to the active sites, reducing the metal uptake by plants [12]. Therefore, the effect of $\mathrm{pH}$ value cannot be ignored during the rhizofiltration process.

\subsection{Nutrients and chemical characteristics of pollutants.}

Concentrations of nutrients have both positive and negative impacts on the metal uptake of plants. In a growing media with high concentrations of nutrients available for plants, adsorbed metals may bind to anions that exist in nutrients. Thus, competition between HM and nutrient cations causes a reduction in metal uptake. In contrast, plant growth is promoted with higher concentrations of nutrients. Subsequently, more metal uptake sites in plants are created, which aid in the rhizofiltration process's removal efficiency. Nonetheless, plants' metal uptake is governed by plants' response towards metal uptake and growth rate [98]. Some organic contaminants are hydrophobic in which the organic contaminants will not dissolve in groundwater. This will increase the difficulty in absorbing organic contaminants from the plant's roots. Cyclodextrins could be used to react with hydrophobic organic contaminants as cyclodextrins act as surfactants and complexing agents [112]. With surfactants' help, the rhizofiltration of hydrophobic organic contaminants could be increased [114-115], so more organic contaminants could be removed from the groundwater.

\section{Conclusions}

Heavy metals and organic contaminants raise environmental concern due to health impacts on terrestrial and aquatic organisms, including human well-being. The consequences of heavy metals in groundwater, a vital module of the ecosystem that provides water for domestic, industrial, and agricultural use, must be acknowledged and mitigated. However, groundwater treatment poses challenges as factors such as natural processes, biogeochemistry, groundwater flow pattern, and soil permeability in the aquifer must be determined to prevent soil profile from deterioration. Therefore, the compatibility between remediation technologies 
and the characteristics of sites must be specified so that the collateral effects of technologies on the environment can be reduced. Rhizofiltration that utilize plants to adsorb and neutralize pollutant in groundwater is a potential environmental-friendly alternative in mitigating groundwater pollution. Nonetheless, this green approach still has several drawbacks that create challenges to become a conventional and widely used technique in remediating groundwater. Hence, further research is required to mitigate these limitations as well as provide more optimal conditions for the rhizofiltration process to be carried out. The removal efficiency of pollutants has to be determined after factors that will impact the site environment. The metal uptake of associated plant species is taken into account. Regular monitoring is then needed to prevent the deterioration of groundwater ecosystems. Lastly, extensive research for proper disposal or possible recycling method of harvested plants can further transfer rhizofiltration towards commercialization.

\section{Funding}

Not applicable.

\section{Acknowledgments}

The authors thank Universitas Pertahanan and Curtin University of Malaysia for facilitating this work. Collaboration from Institut Teknologi Sepuluh Nopember is highly appreciated.

\section{Conflicts of Interest}

The authors declare no conflict of interest.

\section{References}

1. Erakhrumen, A.A. Research Advances in Bioremediation of Soils and Groundwater Using Plant-Based Systems: A Case for Enlarging and Updating Information and Knowledge in Environmental Pollution Management in Developing Countries. In Biomanagement of Metal-Contaminated Soils, Khan, M.S., Zaidi, A., Goel, R., Musarrat, J., Eds. Springer Netherlands: Dordrecht, 2011; https://doi.org/10.1007/978-94-0071914-9_6.

2. Haldar, S.; Ghosh, A. Microbial and plant-assisted heavy metal remediation in aquatic ecosystems: a comprehensive review. 3 Biotech 2020, 10, 205, https://doi.org/10.1007/s13205-020-02195-4.

3. Duruibe, J.O.; Ogwuegbu, M.O.C.; Egwurugwu, J.N. Heavy metal pollution and human biotoxic effects. International Journal of physical sciences 2007, 2, 112-118.

4. Sharma, S.; Nagpal, A.K.; Kaur, I. Appraisal of heavy metal contents in groundwater and associated health hazards posed to human population of Ropar wetland, Punjab, India and its environs. Chemosphere 2019, 227, 179-190, https://doi.org/10.1016/j.chemosphere.2019.04.009.

5. Doyi, I.; Essumang, D.; Gbeddy, G.; Dampare, S.; Kumassah, E.; Saka, D. Spatial distribution, accumulation and human health risk assessment of heavy metals in soil and groundwater of the Tano Basin, Ghana. Ecotoxicol. Environ. Saf. 2018, 165, 540-546, https://doi.org/10.1016/j.ecoenv.2018.09.015.

6. Aryal, M.; Liakopoulou-Kyriakides, M. Bioremoval of heavy metals by bacterial biomass. Environ. Monit. Assess. 2015, 187, 4173, https://doi.org/10.1007/s10661-014-4173-z.

7. Mani, D.; Kumar, C. Biotechnological advances in bioremediation of heavy metals contaminated ecosystems: an overview with special reference to phytoremediation. Int. J. Environ. Sci. Technol. (Tehran) 2014, 11, 843-872, https://doi.org/10.1007/s13762-013-0299-8.

8. Praveen, A.; Pandey, V.C.; Marwa, N.; Singh, D.P. Chapter 15 - Rhizoremediation of Polluted Sites: Harnessing Plant-Microbe Interactions. In Phytomanagement of Polluted Sites, Pandey, V.C., Bauddh, K., Eds. Elsevier: 2019, 389-407, https://doi.org/10.1016/B978-0-12-813912-7.00015-6. 
9. Singh, N.P.; Santal, A.R. Phytoremediation of Heavy Metals: The Use of Green Approaches to Clean the Environment. In Phytoremediation: Management of Environmental Contaminants, Volume 2, Ansari, A.A., Gill, S.S., Gill, R., Lanza, G.R., Newman, L., Eds. Springer International Publishing: Cham, 2015, 115-129. https://doi.org/10.1007/978-3-319-10969-5_10.

10. Anandan, S.; Kumar Ponnusamy, V.; Ashokkumar, M. A review on hybrid techniques for the degradation of organic pollutants in aqueous environment. Ultrason. Sonochem. 2020, 67, 105130, https://doi.org/10.1016/j.ultsonch.2020.105130.

11. Hashim, M.A.; Mukhopadhyay, S.; Sahu, J.N.; Sengupta, B. Remediation technologies for heavy metal contaminated groundwater. J. Environ. Manage. 2011, 92, 2355-2388, https://doi.org/10.1016/j.jenvman.2011.06.009.

12. Tiwari, J.; Ankit; Sweta; Kumar, S.; Korstad, J.; Bauddh, K. Chapter 5 - Ecorestoration of Polluted Aquatic Ecosystems Through Rhizofiltration. In Phytomanagement of Polluted Sites, Pandey, V.C., Bauddh, K., Eds. Elsevier: 2019, 179-201, https://doi.org/10.1016/B978-0-12-813912-7.00005-3.

13. Leong, Y.K.; Chang, J.-S. Bioremediation of heavy metals using microalgae: Recent advances and mechanisms. Bioresour. Technol. 2020, 303, 122886, https://doi.org/10.1016/j.biortech.2020.122886.

14. Zhang, X.; Yang, L.; Li, Y.; Li, H.; Wang, W.; Ye, B. Impacts of lead/zinc mining and smelting on the environment and human health in China. Environ. Monit. Assess. 2012, 184, 2261-2273, https://doi.org/10.1007/s10661-011-2115-6.

15. Neuberger, J.S.; Hu, S.C.; Drake, K.D.; Jim, R. Potential health impacts of heavy-metal exposure at the Tar Creek Superfund site, Ottawa County, Oklahoma. Environ. Geochem. Health 2009, 31, 47-59, https://doi.org/10.1007/s10653-008-9154-0.

16. Almeida, J.C.; Cardoso, C.E.D.; Tavares, D.S.; Freitas, R.; Trindade, T.; Vale, C.; Pereira, E. Chromium removal from contaminated waters using nanomaterials - A review. TrAC, Trends Anal. Chem. 2019, 118, 277-291, https://doi.org/10.1016/j.trac.2019.05.005.

17. Xiaomei, L.; Qitang, W.; Banks, M.K. Effect of Simultaneous Establishment of Sedum Alfredii and Zea Mays on Heavy Metal Accumulation in Plants. Int. J. Phytoremediation 2005, 7, 43-53, https://doi.org/10.1080/16226510590915800.

18. Du, B.; Zhou, J.; Lu, B.; Zhang, C.; Li, D.; Zhou, J.; Jiao, S.; Zhao, K.; Zhang, H. Environmental and human health risks from cadmium exposure near an active lead-zinc mine and a copper smelter, China. Sci. Total Environ. 2020, 720, 137585, https://doi.org/10.1016/j.scitotenv.2020.137585.

19. Singovszka, E.; Balintova, M.; Junakova, N. The impact of heavy metals in water from abandoned mine on human health. SN Applied Sciences 2020, 2, 934, https://doi.org/10.1007/s42452-020-2731-2.

20. Rasheed, H.; Kay, P.; Slack, R.; Gong, Y.Y. Arsenic species in wheat, raw and cooked rice: Exposure and associated health implications. Sci. Total Environ. 2018, 634, 366-373, https://doi.org/10.1016/j.scitotenv.2018.03.339.

21. Gress, J.; de Oliveira, L.M.; da Silva, E.B.; Lessl, J.M.; Wilson, P.C.; Townsend, T.; Ma, L.Q. Cleaninginduced arsenic mobilization and chromium oxidation from CCA-wood deck: Potential risk to children. Environ. Int. 2015, 82, 35-40, https://doi.org/10.1016/j.envint.2015.04.012.

22. World Health, O. Preventing disease through healthy environments: exposure to arsenic: a major public health concern; World Health Organization: 2010. Available online: https://www.who.int/ipcs/features/arsenic.pdf.

23. Pietrangelo, A. Mechanism of Iron Toxicity. In Iron Chelation Therapy, Hershko, C., Ed. Springer US: Boston, MA, 2002, 19-43, https://doi.org/10.1007/978-1-4615-0593-8_2.

24. Hsia, Y.; Liu, R.; Engelmann, H.; Gonser, U. The green stain on the bark of plane trees - A new probe for studying the iron content in air pollution. Hyperfine Interact. 1988, 42, 901-904, https://doi.org/10.1007/BF02395535.

25. Lindqvist, O.; Johansson, K.; Bringmark, L.; Timm, B.; Aastrup, M.; Andersson, A.; Hovsenius, G.; Håkanson, L.; Iverfeldt, Å.; Meili, M. Mercury in the Swedish environment — Recent research on causes, consequences and corrective methods. Water, Air, Soil Pollut. 1991, 55, xi-261, https://doi.org/10.1007/BF00542429.

26. Yang, L.; Zhang, Y.; Wang, F.; Luo, Z.; Guo, S.; Strähle, U. Toxicity of mercury: Molecular evidence. Chemosphere 2020, 245, 125586, https://doi.org/10.1016/j.chemosphere.2019.125586.

27. Vardhan, K.H.; Kumar, P.S.; Panda, R.C. A review on heavy metal pollution, toxicity and remedial measures: Current trends and future perspectives. J. Mol. Liq. 2019, 290, 111197 , https://doi.org/10.1016/j.molliq.2019.111197. 
28. Knox, A.S.; Gamerdinger, A.P.; Adriano, D.C.; Kolka, R.K.; Kaplan, D.I. Sources and practices contributing to soil contamination. Bioremediation of contaminated soils 1999, 37, 53-87.

29. Shahzad, B.; Tanveer, M.; Rehman, A.; Cheema, S.A.; Fahad, S.; Rehman, S.; Sharma, A. Nickel; whether toxic or essential for plants and environment - A review. Plant Physiol. Biochem. 2018, 132, 641-651, https://doi.org/10.1016/j.plaphy.2018.10.014.

30. Rizvi, A.; Parveen, S.; Khan, S.; Naseem, I. Nickel toxicology with reference to male molecular reproductive physiology. Reprod. Biol. 2020, 20, 3-8, https://doi.org/10.1016/j.repbio.2019.11.005.

31. Emeh, C.; Igwe, O.; Onwo, E.S. Potential effect of environmental pollution on the degree of dissolution of iron and aluminium oxides in lateritic soils. Environmental Earth Sciences 2019, 78, 256, https://doi.org/10.1007/s12665-019-8259-3.

32. Nelson, M.; Adams, T.; Ojo, C.; Carroll, M.A.; Catapane, E.J. Manganese toxicity is targeting an early step in the dopamine signal transduction pathway that controls lateral cilia activity in the bivalve mollusc Crassostrea virginica. Comparative Biochemistry and Physiology Part C: Toxicology \& Pharmacology 2018, 213, 1-6, https://doi.org/10.1016/j.cbpc.2018.07.002.

33. Fei, J.-C.; Min, X.-B.; Wang, Z.-X.; Pang, Z.-h.; Liang, Y.-J.; Ke, Y. Health and ecological risk assessment of heavy metals pollution in an antimony mining region: a case study from South China. Environmental Science and Pollution Research 2017, 24, 27573-27586, https://doi.org/10.1007/s11356-017-0310-x.

34. Dardiotis, E.; Aloizou, A.-M.; Sakalakis, E.; Siokas, V.; Koureas, M.; Xiromerisiou, G.; Petinaki, E.; Wilks, M.; Tsatsakis, A.; Hadjichristodoulou, C.; Stefanis, L.; Hadjigeorgiou, G.M. Organochlorine pesticide levels in Greek patients with Parkinson's disease. Toxicology Reports 2020, 7, 596-601, https://doi.org/10.1016/j.toxrep.2020.03.011.

35. Jeddy, Z.; Kordas, K.; Allen, K.; Taylor, E.V.; Northstone, K.; Dana Flanders, W.; Namulanda, G.; Sjodin, A.; Hartman, T.J. Prenatal exposure to organochlorine pesticides and early childhood communication development in British girls. Neurotoxicology $2018, \quad 69, \quad 121-129$, https://doi.org/10.1016/j.neuro.2018.10.003.

36. Yin, S.; Wei, J.; Wei, Y.; Jin, L.; Wang, L.; Zhang, X.; Jia, X.; Ren, A. Organochlorine pesticides exposure may disturb homocysteine metabolism in pregnant women. Sci. Total Environ. 2020, 708, 135146, https://doi.org/10.1016/j.scitotenv.2019.135146.

37. Shah, H.K.; Sharma, T.; Banerjee, B.D. Organochlorine pesticides induce inflammation, ROS production, and DNA damage in human epithelial ovary cells: An in vitro study. Chemosphere 2020, 246, 125691, https://doi.org/10.1016/j.chemosphere.2019.125691.

38. Park, C.M.; Kim, K.-T.; Rhyu, D.Y. Low-concentration exposure to organochlorine pesticides (OCPs) in L6 myotubes and RIN-m5F pancreatic beta cells induces disorders of glucose metabolism. Toxicol. In Vitro 2020, 65, 104767, https://doi.org/10.1016/j.tiv.2020.104767.

39. Joseph, L.; Paulose, S.V.; Cyril, N.; Santhosh, S.K.; Varghese, A.; Nelson, A.B.; Kunjankutty, S.V.; Kasu, S. Organochlorine pesticides in the soils of Cardamom Hill Reserve (CHR), Kerala, India: Geo spatial distribution, ecological and human health risk assessment. Environmental Chemistry and Ecotoxicology 2020, 2, 1-11, https://doi.org/10.1016/j.enceco.2020.01.001.

40. Hadibarata, T.; Syafiuddin, A.; Ghfar A.A. Abudance and distribution of polycyclic aromatic hydrocabrons (PAHs) in sediments of the Mahakam river. Marine Pollut Bull 2019, 149, 110650, https://doi.org/10.1016/j.marpolbul.2019.110650

41. Sah, R.; Baroth, A.; Hussain, S.A. First account of spatio-temporal analysis, historical trends, source apportionment and ecological risk assessment of banned organochlorine pesticides along the Ganga River. Environ. Pollut. 2020, 263, 114229, https://doi.org/10.1016/j.envpol.2020.114229.

42. Awa, S.H.; Hadibarata, T. Removal of heavy metals in contaminated soil by phytoremediation mechanism: A review. Water Air Soil Pollut. 2020, 231, 47, https://doi.org/10.1007/s11270-020-4426-0.

43. Abdel-Shafy, H.I.; Mansour, M.S.M. A review on polycyclic aromatic hydrocarbons: Source, environmental impact, effect on human health and remediation. Egyptian Journal of Petroleum 2016, 25, 107-123, https://doi.org/10.1016/j.ejpe.2015.03.011.

44. Patel, A.B.; Shaikh, S.; Jain, K.R.; Desai, C.; Madamwar, D. Polycyclic Aromatic Hydrocarbons: Sources, Toxicity, and Remediation Approaches. Front. Microbiol. 2020, 11, 2675, https://doi.org/10.3389/fmicb.2020.562813.

45. Alharbi, O.M.L.; Basheer, A.A.; Khattab, R.A.; Ali, I. Health and environmental effects of persistent organic pollutants. J. Mol. Liq. 2018, 263, 442-453, https://doi.org/10.1016/j.molliq.2018.05.029. 
46. Hąc-Wydro, K.; Połeć, K.; Broniatowski, M. The impact of selected Polycyclic Aromatic Hydrocarbons (PAHs) on the morphology, stability and relaxation of ternary lipid monolayers imitating soil bacteria membrane. J. Mol. Liq. 2019, 276, 409-416, https://doi.org/10.1016/j.molliq.2018.12.020.

47. Matsumoto, M.; Hirata-Koizumi, M.; Ema, M. Potential adverse effects of phthalic acid esters on human health: A review of recent studies on reproduction. Regul. Toxicol. Pharmacol. 2008, 50, 37-49, https://doi.org/10.1016/j.yrtph.2007.09.004.

48. Abdel daiem, M.M.; Rivera-Utrilla, J.; Ocampo-Pérez, R.; Méndez-Díaz, J.D.; Sánchez-Polo, M. Environmental impact of phthalic acid esters and their removal from water and sediments by different technologies - $\mathrm{A}$ review. J. Environ. Manage. 2012, 109, 164-178, https://doi.org/10.1016/j.jenvman.2012.05.014.

49. Aminian, O.; Moinfar, Z.; Eftekhari, S.; Esser, A.; Schettgen, T.; Felten, M.; Kaifie, A.; Kraus, T. Association of plasma levels of lipid and polychlorinated biphenyls in Iranian adult. Heliyon 2020, 6, e03775, https://doi.org/10.1016/j.heliyon.2020.e03775.

50. Donat-Vargas, C.; Moreno-Franco, B.; Laclaustra, M.; Sandoval-Insausti, H.; Jarauta, E.; Guallar-Castillon, P. Exposure to dietary polychlorinated biphenyls and dioxins, and its relationship with subclinical coronary atherosclerosis: The Aragon Workers' Health Study. Environ. Int. 2020, 136, 105433, https://doi.org/10.1016/j.envint.2019.105433.

51. Wang, H.; Hu, J.; Xu, K.; Tang, X.; Xu, X.; Shen, C. Biodegradation and chemotaxis of polychlorinated biphenyls, biphenyls, and their metabolites by Rhodococcus spp. Biodegradation 2018, 29, 1-10, https://doi.org/10.1007/s10532-017-9809-6.

52. Jiang, L.; Luo, C.; Zhang, D.; Song, M.; Sun, Y.; Zhang, G. Biphenyl-Metabolizing Microbial Community and a Functional Operon Revealed in E-Waste-Contaminated Soil. Environ. Sci. Technol. 2018, 52, 85588567, https://doi.org/10.1021/acs.est.7b06647.

53. Zhao, S.; Breivik, K.; Liu, G.; Zheng, M.; Jones, K.C.; Sweetman, A.J. Long-Term Temporal Trends of Polychlorinated Biphenyls and Their Controlling Sources in China. Environ. Sci. Technol. 2017, 51, 28382845, https://doi.org/10.1021/acs.est.6b05341.

54. Latif, M.T.; Abd Hamid, H.H.; Ahamad, F.; Khan, M.F.; Nadzir, M.S.M.; Othman, M.; Sahani, M.; Wahab, M.I.A.; Mohamad, N.; Uning, R. BTEX compositions and its potential health impacts in Malaysia. Chemosphere 2019, 237, 124451, https://doi.org/10.1016/j.chemosphere.2019.124 451.

55. Golkhorshidi, F.; Sorooshian, A.; Jafari, A.J.; Baghani, A.N.; Kermani, M.; Kalantary, R.R.; Ashournejad, Q.; Delikhoon, M. On the nature and health impacts of BTEX in a populated middle eastern city: Tehran, Iran. Atmospheric Pollution Research 2019, 10, 921-930, https://doi.org/10.1016/j.apr.2018.12.020.

56. Masih, A.; Lall, A.S.; Taneja, A.; Singhvi, R. Inhalation exposure and related health risks of BTEX in ambient air at different microenvironments of a terai zone in north India. Atmos. Environ. 2016, 147, 55-66, https://doi.org/10.1016/j.atmosenv.2016.09.067.

57. Zacharia, J.T. Degradation Pathways of Persistent Organic Pollutants (POPs) in the Environment. In Persistent Organic Pollutants, IntechOpen: 2019, https://doi.org/10.5772/intechopen.79645.

58. Bao, L.-J.; Maruya, K.A.; Snyder, S.A.; Zeng, E.Y. China's water pollution by persistent organic pollutants. Environ. Pollut. 2012, 163, 100-108, https://doi.org/10.1016/j.envpol.2011.12.022.

59. Ren, M.; Wu, J.; Shao, F.; Liu, X. Soil infiltration and conservative solute transport characteristics with different viscosity of hydroxypropyl methyl cellulose. Soil Sci. Soc. Am. J. 2020, 84, 1067-1079, https://doi.org/10.1002/saj2.20103.

60. Sun, J.; Pan, L.; Tsang, D.C.W.; Zhan, Y.; Zhu, L.; Li, X. Organic contamination and remediation in the agricultural soils of China: A critical review. Sci. Total Environ. 2018, 615, 724-740, https://doi.org/10.1016/j.scitotenv.2017.09.271.

61. Motlagh, A.M.; Yang, Z.; Saba, H. Groundwater quality. Water Environ. Res. 2020, 92, 1649-1658, https://doi.org/10.1002/wer.1412.

62. Ashraf, M.A. Persistent organic pollutants (POPs): a global issue, a global challenge. Environmental Science and Pollution Research 2017, 24, 4223-4227, https://doi.org/10.1007/s11356-015-5225-9.

63. Wick, K.; Heumesser, C.; Schmid, E. Groundwater nitrate contamination: Factors and indicators. J. Environ. Manage. 2012, 111, 178-186, https://doi.org/10.1016/j.jenvman.2012.06.030.

64. Sadef, Y.; Poulsen, T.G.; Bester, K. Impact of compost process temperature on organic micro-pollutant degradation. Sci. Total Environ. 2014, 494-495, 306-312, https://doi.org/10.1016/j.scitotenv.2014.07.003. 
65. Rivier, P.-A.; Havranek, I.; Coutris, C.; Norli, H.R.; Joner, E.J. Transfer of organic pollutants from sewage sludge to earthworms and barley under field conditions. Chemosphere 2019, 222, 954-960, https://doi.org/10.1016/j.chemosphere.2019.02.010.

66. Ali, M.H.H.; Al-Qahtani, K.M.; El-Sayed, S.M. Enhancing photodegradation of 2,4,6 trichlorophenol and organic pollutants in industrial effluents using nanocomposite of $\mathrm{TiO} 2$ doped with reduced graphene oxide. The Egyptian Journal of Aquatic Research 2019, 45, 321-328, https://doi.org/10.1016/j.ejar.2019.08.003.

67. Charles, J.; Crini, G.; Morin-Crini, N.; Badot, P.-M.; Trunfio, G.; Sancey, B.; de Carvalho, M.; Bradu, C.; Avramescu, S.; Winterton, P.; Gavoille, S.; Torri, G. Advanced oxidation (UV-ozone) and cyclodextrin sorption: Effects of individual and combined action on the chemical abatement of organic pollutants in industrial effluents. Journal of the Taiwan Institute of Chemical Engineers 2014, 45, 603-608, https://doi.org/10.1016/j.jtice.2013.06.023.

68. Castillo, M.; Alonso, M.C.; Riu, J.; Barceló, D. Identification of Polar, Ionic, and Highly Water Soluble Organic Pollutants in Untreated Industrial Wastewaters. Environ. Sci. Technol. 1999, 33, 1300-1306, https://doi.org/10.1021/es981012b.

69. Mishra, H.; Karmakar, S.; Kumar, R.; Kadambala, P. A long-term comparative assessment of human health risk to leachate-contaminated groundwater from heavy metal with different liner systems. Environmental Science and Pollution Research 2018, 25, 2911-2923, https://doi.org/10.1007/s11356-017-0717-4.

70. Christensen, T.H.; Kjeldsen, P.; Bjerg, P.L.; Jensen, D.L.; Christensen, J.B.; Baun, A.; Albrechtsen, H.-J.; Heron, G. Biogeochemistry of landfill leachate plumes. Appl. Geochem. 2001, 16, 659-718, https://doi.org/10.1016/S0883-2927(00)00082-2.

71. Ančić, M.; Huđek, A.; Rihtarić, I.; Cazar, M.; Bačun-Družina, V.; Kopjar, N.; Durgo, K. PHYSICO chemical properties and toxicological effect of landfill groundwaters and leachates. Chemosphere 2020, 238, 124574, https://doi.org/10.1016/j.chemosphere.2019.124574.

72. Xue, H.; Li, J.; Xie, H.; Wang, Y. Review of Drug Repositioning Approaches and Resources. Int. J. Biol. Sci. 2018, 14, 1232-1244, https://doi.org/10.7150/ijbs.24612.

73. Varjani, S.J.; Gnansounou, E.; Pandey, A. Comprehensive review on toxicity of persistent organic pollutants from petroleum refinery waste and their degradation by microorganisms. Chemosphere 2017, 188, 280-291, https://doi.org/10.1016/j.chemosphere.2017.09.005.

74. Nazifa, T.H.; Ahmad, M.A.; Hadibarata, T.; Salmiati, A.A. Bioremediation of diesel oil spill by filamentous fungus Trichoderma reesei H002 in aquatic environment. International J. Integrated Eng. 2018, 10(9), 103107 https://doi.org/10.30880/ijie.2018.10.09.019.

75. Ossai, I.C.; Ahmed, A.; Hassan, A.; Hamid, F.S. Remediation of soil and water contaminated with petroleum hydrocarbon: A review. Environmental Technology \& Innovation 2020, 17, 100526, https://doi.org/10.1016/j.eti.2019.100526.

76. Jaishankar, M.; Tseten, T.; Anbalagan, N.; Mathew, B.B.; Beeregowda, K.N. Toxicity, mechanism and health effects of some heavy metals. Interdiscip. Toxicol. 2014, 7, 60-72, https://doi.org/10.2478/intox-2014-0009.

77. Obasi, P.N.; Akudinobi, B.E.B. Heavy metals occurrence, assessment and distribution in water resources of the lead-zinc mining areas of Abakaliki, Southeastern Nigeria. Int. J. Environ. Sci. Technol. (Tehran) 2019, 16, 8617-8638, https://doi.org/10.1007/s13762-019-02489-y.

78. Sharma, J.K.; Juwarkar, A.A. Phytoremediation: General Account and Its Application. In Plant Biology and Biotechnology: Volume II: Plant Genomics and Biotechnology, Bahadur, B., Venkat Rajam, M., Sahijram, L., Krishnamurthy, K.V., Eds. Springer India: New Delhi, 2015; 673-684, https://doi.org/10.1007/978-81322-2283-5_34.

79. Anand, M.; Taneja, A. Organochlorine pesticides residue in placenta and their influence on anthropometric measures of infants. Environ. Res. 2020, 182, 109106, https://doi.org/10.1016/j.envres.2019.109106.

80. Tang, Z.; Huang, Q.; Nie, Z.; Yang, Y.; Yang, J.; Qu, D.; Cheng, J. Levels and distribution of organochlorine pesticides and hexachlorobutadiene in soils and terrestrial organisms from a former pesticide-producing area in Southwest China. Stoch. Environ. Res. Risk Assess. 2016, 30, 1249-1262, https://doi.org/10.1007/s00477015-1144-z.

81. Zhang, C.; Song, P.; Xia, Q.; Li, X.; Wang, J.; Zhu, L.; Wang, J. Responses of Microbial Community to Di(2-ethylhcxyl) Phthalate Contamination in Brown Soil. Bull. Environ. Contam. Toxicol. 2020, 104, 820-827, https://doi.org/10.1007/s00128-020-02878-x.

82. Mello, F.V.; Land, M.G.P.; Costa, E.S.; Teodósio, C.; Sanchez, M.-L.; Bárcena, P.; Peres, R.T.; Pedreira, C.E.; Alves, L.R.; Orfao, A. Maturation-associated gene expression profiles during normal human bone marrow erythropoiesis. Cell Death Discovery 2019, 5, 69, https://doi.org/10.1038/s41420-019-0151-0.

83. Scullion, J. Remediating polluted soils. Naturwissenschaften 2006, 93, 51-65, https://doi.org/10.1007/s00114-005-0079-5.

https://biointerfaceresearch.com/ 
84. Amonette, J.E.; Szecsody, J.E.; Schaef, H.T.; Gorby, Y.A.; Fruchter, J.S.; Templeton, J.C. Abiotic reduction of aquifer materials by dithionite: a promising in-situ remediation technology; Pacific Northwest Lab., Richland, WA (United States): 1994, https://doi.org/10.2172/43791.

85. Tuin, B.J.W.; Senden, M.M.G.; Tels, M. Extractive Cleaning of Heavy Metal Contaminated Clay Soils. In Proceedings of Environ. Technol., Dordrecht, 1987; 520-528.

86. Lombi, E.; Zhao, F.-J.; Zhang, G.; Sun, B.; Fitz, W.; Zhang, H.; McGrath, S.P. In situ fixation of metals in soils using bauxite residue: chemical assessment. Environ. Pollut. 2002, 118, 435-443, https://doi.org/10.1016/S0269-7491(01)00294-9.

97. Cristaldi, A.; Conti, G.O.; Jho, E.H.; Zuccarello, P.; Grasso, A.; Copat, C.; Ferrante, M. Phytoremediation of contaminated soils by heavy metals and PAHs. A brief review. Environmental Technology \& Innovation 2017, 8, 309-326, https://doi.org/10.1016/j.eti.2017.08.002.

88. Raymond, R. Reclamation of hydrocarbon contaminated groundwater s. Google Patents: 1974.

89. Leung, H.M.; Ye, Z.H.; Wong, M.H. Interactions of mycorrhizal fungi with Pteris vittata (As hyperaccumulator) in As-contaminated soils. Environ. Pollut. 2006, 139, 1-8, https://doi.org/10.1016/j.envpol.2005.05.009.

90. Vidic, R.D.; Pohland, F.G. Treatment Walls. Technology Evaluation Report TE-96-01. Ground-Water Remediation Technologies Analysis Center. Pittsburgh. USA 1996.

91. Leštan, D.; Luo, C.-1.; Li, X.-d. The use of chelating agents in the remediation of metal-contaminated soils: A review. Environ. Pollut. 2008, 153, 3-13, https://doi.org/10.1016/j.envpol.2007.11.015.

92. Iram, S.; Ahmad, I.; Javed, B.; Yaqoob, S.; Akhtar, K.; Kazmi, M.R.; Rand Zaman, B. Fungal tolerance to heavy metals. Pak J Bot 2009, 41, 2583-2594.

93. Lang, I.; Wernitznig, S. Sequestration at the cell wall and plasma membrane facilitates zinc tolerance in the moss Pohlia drummondii. Environ. Exp. Bot. 2011, 74, 186-193, https://doi.org/10.1016/j.envexpbot.2011.05.018.

94. Tsao, D.T. Overview of Phytotechnologies. In Phytoremediation, Tsao, D.T., Ed. Springer Berlin Heidelberg: Berlin, Heidelberg, 2003; 1-50, https://doi.org/10.1007/3-540-45991-X_1.

95. Qiu, Z.; Tan, H.; Zhou, S.; Cao, L. Enhanced phytoremediation of toxic metals by inoculating endophytic Enterobacter sp. CBSB1 expressing bifunctional glutathione synthase. J. Hazard. Mater. 2014, 267, 17-20, https://doi.org/10.1016/j.jhazmat.2013.12.043.

96. Chiang, P.N.; Chiu, C.-Y.; Wang, M.K.; Chen, B.-T. Low-Molecular-Weight Organic Acids Exuded by Millet (Setaria italica (L.) Beauv.) Roots and Their Effect on the Remediation of Cadmium-Contaminated Soil. Soil Sci. 2011, 176, https://doi.org/10.1097/SS.0b013e318202fdc9.

97. Veselý, T.; Trakal, L.; Neuberg, M.; Száková, J.; Drábek, O.; Tejnecký, V.; Balíková, M.; Tlustoš, P. Removal of Al, Fe and Mn by Pistia stratiotes L. and its stress response. Open Life Sciences 2012, 7, 1037 1045, https://doi.org/10.2478/s11535-012-0099-z.

98. Thayaparan, M.; Iqbal, S.S.; Chathuranga, P.K.D.; Iqbal, M.C.M. Rhizofiltration of Pb by Azolla pinnata. International Journal of Environmental Sciences 2013, 3, 1811-1821, https://doi.org/10.6088/ijes.2013030600002.

99. Yadav, B.K.; Siebel, M.A.; van Bruggen, J.J.A. Rhizofiltration of a Heavy Metal (Lead) Containing Wastewater Using the Wetland Plant Carex pendula. CLEAN - Soil, Air, Water 2011, 39, 467-474, https://doi.org/10.1002/clen.201000385.

100.Hegazy, A.K.; Abdel-Ghani, N.T.; El-Chaghaby, G.A. Phytoremediation of industrial wastewater potentiality by Typha domingensis. Int. J. Environ. Sci. Technol. (Tehran) 2011, 8, 639-648, https://doi.org/10.1007/BF03326249.

101.Juárez-Santillán, L.F.; Lucho-Constantino, C.A.; Vázquez-Rodríguez, G.A.; Cerón-Ubilla, N.M.; BeltránHernández, R.I. Manganese accumulation in plants of the mining zone of Hidalgo, Mexico. Bioresour. Technol. 2010, 101, 5836-5841, https://doi.org/10.1016/j.biortech.2010.03.020.

102.Hammad, D.M. Cu, Ni and $\mathrm{Zn}$ phytoremediation and translocation by water hyacinth plant at different aquatic environments. Australian Journal of Basic and Applied Sciences 2011, 5, 11-22.

103.Llugany, M.; Miralles, R.; Corrales, I.; Barceló, J.; Poschenrieder, C. Cynara cardunculus a potentially useful plant for remediation of soils polluted with cadmium or arsenic. Journal of Geochemical Exploration 2012, 123, 122-127, https://doi.org/10.1016/j.gexplo.2012.06.016.

104.El-Aassar, M.R.; Fakhry, H.; Elzain, A.A.; Farouk, H.; Hafez, E.E. Rhizofiltration system consists of chitosan and natural Arundo donax L. for removal of basic red dye. Int. J. Biol. Macromol. 2018, 120, 1508-1514, https://doi.org/10.1016/j.ijbiomac.2018.09.159. 
105.Tan, W.; Yu, H.; Huang, C.; Li, D.; Zhang, H.; Zhao, X.; Li, R.; Wang, G.; Zhang, Y.; He, X.; Xi, B. Intercropping wheat and maize increases the uptake of phthalic acid esters by plant roots from soils. $J$. Hazard. Mater. 2018, 359, 9-18, https://doi.org/10.1016/j.jhazmat.2018.07.026.

106. Sharma, S.; Singh, B.; Manchanda, V.K. Phytoremediation: role of terrestrial plants and aquatic macrophytes in the remediation of radionuclides and heavy metal contaminated soil and water. Environmental Science and Pollution Research 2015, 22, 946-962, https://doi.org/10.1007/s11356-014-3635-8.

107. Brix, H. Do macrophytes play a role in constructed treatment wetlands? Water Sci. Technol. 1997, 35, 1117, https://doi.org/10.1016/S0273-1223(97)00047-4.

108.Chang, J.; Fan, X.; Sun, H.; Zhang, C.; Song, C.; Chang, S.X.; Gu, B.; Liu, Y.; Li, D.; Wang, Y.; Ge, Y. Plant species richness enhances nitrous oxide emissions in microcosms of constructed wetlands. Ecol. Eng. 2014, 64, 108-115, https://doi.org/10.1016/j.ecoleng.2013.12.046.

109.Zheng, Y.; Wang, X.; Dzakpasu, M.; Zhao, Y.; Ngo, H.H.; Guo, W.; Ge, Y.; Xiong, J. Effects of interspecific competition on the growth of macrophytes and nutrient removal in constructed wetlands: A comparative assessment of free water surface and horizontal subsurface flow systems. Bioresour. Technol. 2016, 207, 134141, https://doi.org/10.1016/j.biortech.2016.02.008.

110.Mahmoud, A.E.D.; Fawzy, m.; Radwan, A. Optimization of Cadmium (CD2+) removal from aqueous solutions by novel biosorbent. Int. J. Phytoremediation 2016, 18, 619-625, https://doi.org/10.1080/15226514.2015.1086305.

111. Iftikhar, A.R.; Bhatti, H.N.; Hanif, M.A.; Nadeem, R. Kinetic and thermodynamic aspects of Cu(II) and $\mathrm{Cr}$ (III) removal from aqueous solutions using rose waste biomass. J. Hazard. Mater. 2009, 161, 941-947, https://doi.org/10.1016/j.jhazmat.2008.04.040.

112.Komives, T.; Gullner, G.; Bittsanszky, A.; Pascal, S.; Laurent, F. Phytoremediation of persistent organic pollutants. Cereal Research Communications $\quad$ 2009, https://doi.org/10.1556/CRC.37.2009.Suppl.4.

113.Yu, Q.; Kaewsarn, P. Fixed-bed study for copper (II) removal from aqueous solutions by marine alga Durvillaea potatorum. Environ. Technol. 1999, 20, 1005-1008.

114.Gao, Y.-Z.; Ling, W.-T.; Zhu, L.-Z.; Zhao, B.-W.; Zheng, Q.-S. Surfactant-Enhanced Phytoremediation of Soils Contaminated with Hydrophobic Organic Contaminants: Potential and Assessment. Pedosphere 2007, 17, 409-418, https://doi.org/10.1016/S1002-0160(07)60050-2.

115.Kristanti, R.A.; Toyama, T.; Hadibarata, T.; Tanaka, Y.; Mori, K. Sustainable removal of nitrophenols by rhizoremediation using four strains of bacteria and giant duckweed (Spirodela polyrhiza). Water air soil pollut 2014, 225, 1928. https://doi.org/10.1007/s11270-014-1928-7. 